\title{
SORGHUM CULTURE IN THE SOUTH OF UKRAINE, STATE OF PRODUCTION, USE AND POSSIBILITY OF PROCESSING INTO BIOETHANOL
}

\author{
Gamayunova V. V., Khonenko L. G., Kovalenko O. O.
}

\section{INTRODUCTION}

In recent decades, more and more attention has been paid to finding ways to use energy resources obtained from renewable energy sources, especially through the use of plant raw materials. First of all, this is due to the instability of prices for fossil energy sources and the threat of depletion of their reserves.

The solution to the energy problem is to transfer existing technologies to alternative renewable fuels, as well as create and implement new environmentally friendly and energy-efficient technologies. In scientific circles, various options for the production of biofuels are carefully considered, taking into account natural, economic and environmental aspects.

It is predicted that by the middle of the $21^{\text {st }}$ century, alternative energy will provide almost half of the energy resources, and biomass will provide more than $20 \%$. If you grow biomass in fields that are practically not used, or are not used enough, the efficiency of this share for Ukraine can increase to $25 \%$.

The production of biological fuels, such as bioethanol, biodiesel, biogas, etc. is a priority area in the modern world production of liquid fuels. Ukraine also has all the objective prerequisites for organizing the production of bioethanol on a large scale. However, it is worth noting that the scientific progress in the field of opportunities, prospects and efficiency of using biological fuels is insignificant, leaving most of the key issues in this area open for research.

The feasibility of this will be determined by the availability of affordable and cheap vegetable raw materials. For the arid conditions of the south of Ukraine, the most promising from this point of view are sorghum crops, which are characterized by high productivity potential, have increased indicators of drought-heat-resistant and salt-tolerant. 
In Ukraine, sorghum began to be grown in the mid of $19^{\text {th }}$ century as a fodder crop. According to long-term research results of the state service for the protection of rights to plant varieties, in arid regions of Ukraine, the yield of sorghum grain is $27 \%$ higher than the yield of corn. Its main areas in our country are concentrated in the southern region.

In the context of the aggravation of the energy situation, the main reason hindering the further development of sorghum production in Ukraine is the insufficient level of technological support, namely:

- uncertainty of the most appropriate growing regions for sorghum crops;

- high level of discrepancies in production recommendations, for almost all agricultural activities;

- insufficient availability of domestic varieties and hybrids adapted to specific production zones;

- insufficient availability of antidotes for the use of the sorghum weed protection system;

- weak technical security of most agricultural activities;

- underdevelopment of the sorghum crop production market.

In connection with the above data, there is an urgent need to develop elements of sorghum crop cultivation technology in order to realize the potential of this crop, improve the grain balance and food security of Ukraine. Since climate change requires a revision of crop rotations in favor of drought-resistant crops, sorghum is one of the most promising crops for growing for grain, green fodder and especially for the production of an alternative fuel as biofuels. The relevance of in-depth research of this crop, assessment of the state and potential of grain sorghum plants in Ukraine, the most important components of their rational and versatile use is obvious and appropriate.

\section{State and prospects of sorghum cultivation in world agriculture}

Among the many crops suitable for the production of ethanol, sorghum is considered one of the most promising. From one hectare of sugar sorghum, which contains $18-20 \%$ of sugars, you can get $25-30 \mathrm{~kg}$ of sugar syrup [3]. It has high photosynthetic efficiency and it can form a powerful biomass rich in energy in a short growing season. In addition, sorghum contains most of its energy in substances that are easily converted to ethanol. In sugar sorghum, such a substance is a complex of sugars in the juice of the stems, in grain sorghum such substance is grain starch. Grain sorghum has a significantly higher starch yield (70-74 \%) than, for example, corn yield (67-72\%). Therefore, this crop is the 
future of bioethanol production. If you use stems and grain for the production of bioethanol, you can get up to 7 thousand liters/ha per year. In addition, sorghum can be successfully grown in Steppe and foreststeppe zones, with high yields ${ }^{1}$.

In the United States, sorghum is one of the main crops for the production of bioethanol, which provides an alcohol yield 25-30\% higher than corn and wheat (Fig. 1).

\section{Country}

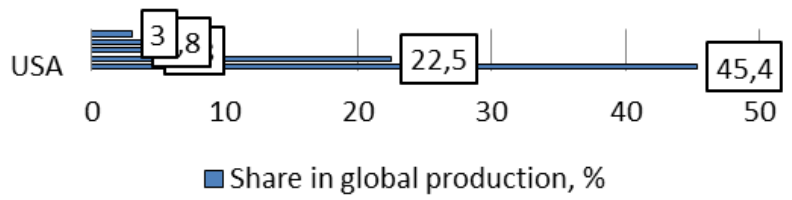

Source: International Energy Agency (IEA)

Fig. 1. Top 5 bioethanol producers

Source: electronic resource http://www.ukrsugar.com/uk/post/biopalivomajbutne-cukrovoi-galuzi-ukraini

Every second ton of sugar entering the world market comes from Brazil, with less than half of the cane is processed into sugar and $60 \%$ of it is processed into ethanol. In Brazil, since the $70 \mathrm{~s}, 50 \%$ of automobile fuel was replaced with ethanol, and there is a law that requires adding at least $20 \%$ ethanol to gasoline ${ }^{2}$. In Brazil, the development of bioethanol production was dictated by the need to support sugar producers, who found themselves in a difficult economic situation due to the introduction of quotas for the supply of their products to a number of countries, including the EU.

EU directives also set the rate of bioethanol in automobile fuel, but at the level of $10 \%$, since emissions of harmful aerosol particles are reduced by 50 , and emissions of carbon monoxide are reduced by $30 \%$. All gasoline sold in the EU usually contains $5 \%$ ethanol (E5 - "E" means ethanol, and " 5 " means percentage of ethanol). However, the vast

1 Продан I. У боргу перед сорго. URL: https://www.zerno-ua.com/ journals/2018/dekabr-2018-god/u-borgu-pered-sorgo/
2 Біопалив
майбутнє
цукрової
галузі України.

URL: http://www.ukrsugar.com/uk/post/biopalivo-majbutne-cukrovoi-galuzi-ukraini. 
majority of commercially available gasoline-powered vehicles built since 2000 can run on a mixture of gasoline up to $10 \%$ ethanol, known as E10. The E10 can be used in almost $90 \%$ of all gasoline-powered vehicles in Europe and $99.7 \%$ of gasoline-powered vehicles produced since 2010 yr. Currently, E10 accounts for $32 \%$ of gasoline sales in France and $63 \%$ in Finland. In 2016 yr, its share in the gasoline market in Germany was $12.6 \%$. In countries where the E10 is available, it is only a few cents cheaper than the E5, and there is no significant difference in fuel consumption between the E10 and E5 gasoline classes.

As for the sorghum segment in Ukraine, the volume of production of this crop does not allow our country to enter the top 10 world producers, but in terms of export volumes, according to USDA estimates, Ukraine is among the top five key world exporters.

Sorghum is cultivated in more than a hundred countries around the world. The global volume of sorghum production for 30 years ranges from 55-70 million tons per year (Fig. 2).

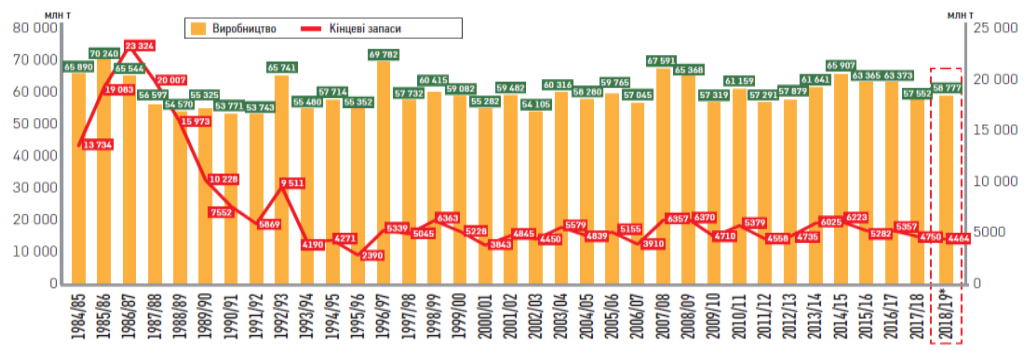

Fig. 2. Global sorghum production and final reserves during 1985/1986 yrs and 2018/2019yrs*Marketing Year* Prognosis

Source: electronic resource http://agro-business.com.ua/agro/ekonomichnyihektar/item/7957-perspektyvnyi-svitovyi-rynok-sorho.html

In the world production of grain crops, the share of sorghum is only $3 \%$ of their total production ${ }^{3}$.

The number of countries growing more than 1 million tons of sorghum increased from 7 in $1990 \mathrm{yr}$ up to 12 in $2014 \mathrm{yr}$, when Ethiopia (+ more than 3.3 million tons), Australia (+ more than 3.3 million tons) and Brazil (+ more than 2 million tons) joined this group. In general, the

3 Перспективний ринок сорго. URL: http://agro-business.com.ua/agro/ ekonomichnyi-hektar/item/7957-perspektyvnyi-svitovyi-rynok-sorho.html. 
"millionaire" countries grew 45.4 million tons of sorghum in $1990 \mathrm{yr}$, and they grew 49.9 million tons in $2014 \mathrm{yr}$, or they grew 79.9 and $72.4 \%$ of the total world volumes, respectively. As with other crops, the number of countries engaged in sorghum cultivation has significantly increased from 94 to $106^{4}$.

In recent years, the world's sorghum acreage has reached 42.4-43.8 million hectares (fig. 3), and the gross harvest ranged from 60-65 million tons.

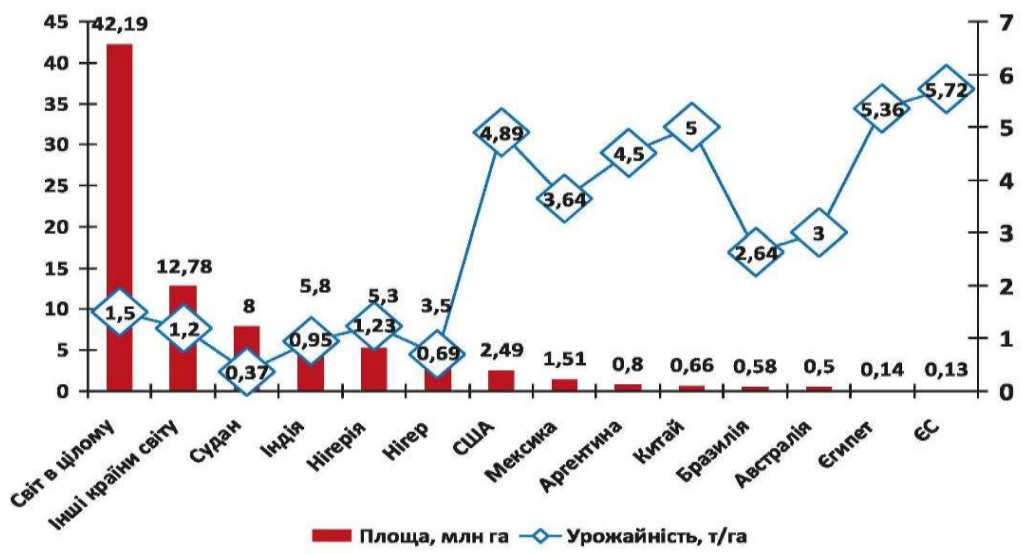

Fig. 3. Area and yield of sorghum in the world in 2016-2017 yrs Marketing Year

Source: electronic resource http://agro-business.com.ualagro/ ekonomichnyi-hektar/item/7957-perspektyvnyi-svitovyi-rynok-sorho.html

The average yield of sorghum in the world in $2016 \mathrm{yr}$ did not exceed $1.50 \mathrm{t} / \mathrm{ha}$ (from $0.37 \mathrm{t} / \mathrm{ha}$ in Sudan up to $5.72 \mathrm{t} / \mathrm{ha}$ in the EU countries.

Sorghum is an alternative to corn also because now the cost of the latter has increased significantly. Even the USDA announced an agricultural strategy until $2027 \mathrm{yr}$, which provides for an increase in sorghum acreage to 2.7 million hectares in general, in particular by 400 thousand hectares in $2018 \mathrm{yr}$, which is $17 \%$ more than in 2017.

Although now, despite the decline in demand from China, a good import potential on the world market is noted precisely from the countries of the European Union, Japan, Mexico, Sudan and Chile. First, demand is increasing in those countries where this culture is traditional,

${ }^{4}$ Супіханов Б. Нішеві культури. Вісник аграрної науки. 2017. № 4. С. 60. 
due to the rapid growth of the population and a significant increase in its well-being. Second, demand is growing in countries where this crop is new to the consumer basket. For example, the EU imported 800 thousand tons sorghum in $2019 \mathrm{yr}$, which is $91 \%$ more compared to 2017/18 yrs, and this is not only due to mass immigration from countries where sorghum is a traditional product, but also due to the growing popularity of gluten-free products (one of which is sorghum), as well as a healthy diet (which values sorghum for its high content of vitamins and antioxidants). In addition, sorghum is used as an energy and fodder crop.

Now it is more expensive than corn, and the cost of growing it is much lower: grain prices are set in the range of 4000-5600 UAH/t CPT.

\section{State and prospects of sorghum crop cultivation and their processing in Ukraine}

On the territory of Ukraine, sorghum began to be grown at the beginning of the XX century. The expediency of growing sorghum in arid and semi-arid areas is primarily due to its high drought resistance, productivity and versatility of use.

According to G. Popova, sorghum, for example, is best suited for growing in the changing climatic conditions of Ukraine, having a high feed quality with a protein content of $12-14 \%$ and $118-130 \mathrm{k}$ units in grain, $24-25 \mathrm{k}$ units. in green mass and $22-23 \mathrm{k}$ units. in the silo ${ }^{5}$.

In Ukraine, sorghum is mainly grown in the southern and central regions. During the period from $1950 \mathrm{yr}$ to $1987 \mathrm{yr}$, the acreage under this crop increased from 6.6 thousand up to 93.5 thousand hectares.

In the early $80 \mathrm{~s}$ of the $20^{\text {th }}$ century, Ukrainian scientists scientifically justified the increase in sorghum acreage in the southern regions of Ukraine. A lot of work was carried out by Doctor of Agricultural Sciences, Professor M. A. Shepel, who justified that in the southern regions of Ukraine the area under the grain sorghum crop should be expanded to 1.8 million hectares ${ }^{6}$.

However, in the conditions of extensive agriculture that developed in the early 90s, and with cheaper energy carriers and insufficient amounts of high-quality seeds, farms were not interested in increasing the area under sorghum.

${ }^{5}$ Попова Г. Врятуватися від спеки. Агро\$гроші. 2013. № 1. С. 18.

${ }^{6}$ Федорчук М., Коковіхін С., Каленська С. та ін. Агротехнологічні аспекти вирощування енергетичних культур в умовах Півдня України : навчальний посібник. Херсон : ФОП Бояркін Д. М., 2017. С. 130. 
In 1989-1990 yrs the acreage under sorghum plants decreased down to 26.1-26.9 thousand, and in 1993-1997 yrs it decreased down to 5.4-10.4 thousand hectares [6]. Since $2003 \mathrm{yr}$ the area under grain sorghum in Ukraine has again begun to increase from 22.9 thousand hectares up to 146.2 thousand hectares in $2013 \mathrm{yr}$. The average grain yield ranged from $1.29 \mathrm{t} / \mathrm{ha}$ in $2003 \mathrm{yr}$ up to $2.68 \mathrm{t} / \mathrm{ha}$ in $2005 \mathrm{yr}$.

With the creation of early-maturing varieties and hybrids, it became possible to grow grain sorghum in territories up to $50-52^{\circ} \mathrm{N}$, and sugar sorghum and Sudanese sorghum hybrids for green fodder and haylage up to $55^{\circ} \mathrm{N}$, that is, almost throughout Ukraine ${ }^{7}$.

The main deterrent to increasing the acreage under the crop was the lack of an antidote for seed treatment and the impossibility of using herbicides in crops. Since 2004-2007 yrs, Syngenta LLC, in cooperation with Reilin state enterprise, has developed a technology for growing sorghum hybrids for the conditions of the southern and central parts of the steppe of Ukraine. This technology was based on the use of seeds of modern sorghum hybrids treated with the concept III antidote, which makes it possible to use herbicides that do not destroy or harm sorghum plants. With the introduction of this technology in Ukrainian farms, sorghum acreage began to grow significantly - from 5 thousand hectares in $2000 \mathrm{yr}$ up to 180 thousand hectares in $2008 \mathrm{yr}$ and to more than 200 thousand hectares in $2014 \mathrm{yr}^{8}$. In $2016 \mathrm{yr}$ according to the Ministry of Agrarian Policy and Food of Ukraine, grain sorghum occupied about 84 thousand hectares, gross collections amounted to 273.7 thousand tons (Fig. 4).

7 Бойко М. Агробіологічне обгрунтування елементів технології вирощування гібридів сорго зернового в Південному Степу України : дис. ... канд. с.-г. наук : 06.01 .09 «Рослинництво». Державний вищий навчальний заклад «Херсонський державний аграрний університет». Херсон, 2017. С. 185.

8 Звіт лабораторії селекції сорго Інституту зернового господарства НААН України за 2006-2011 рр. 23 с. 


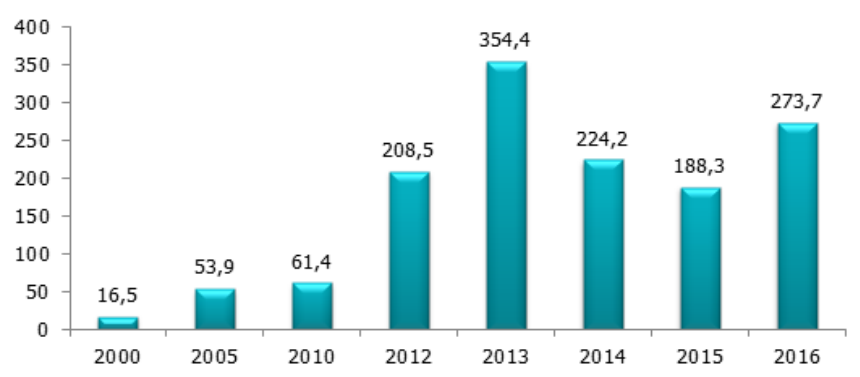

Fig. 4. Dynamics of gross sorghum harvest in Ukraine, thousands of tons

Source: electronic resource https://pro-consulting.ua/ua/pressroom/ne-tolkodlya-venikov-vyrashivanie-sorgo-na-yuge-ukrainy-mozhet-prinosit-horoshuyu-pribyl

In Ukraine, sorghum is grown mainly in steppe and forest-steppe zones. The area sown for sorghum in the steppe zone has undergone significant changes. So, in $2011 \mathrm{yr}$ it was 68.0 thousand hectares, in $2012 \mathrm{yr}$ it was 160.4 thousand hectares, and in $2013 \mathrm{yr}$ it was 134.3 thousand hectares. This was especially true in Odessa (in $2011 \mathrm{yr}$ as 13.0; in $2012 \mathrm{yr}$ as 30.3 ; in $2013 \mathrm{yr}$ as 21.6 thousand hectares), Mykolaiv (13.1; 42.5; 28.2 thousand hectares) and Dnipropetrovsk regions $(8.9 ; 20.9 ; 17.0 \text { thousand hectares, respectively })^{9}$. According to the site 4sg.com.ua in $2017 \mathrm{yr}$ the total area of Ukrainian land allocated for sorghum was 104.74 thousand hectares, in particular in the northern Black Sea region, exceeded 77.7 thousand hectares (Fig. 5).

In 2018, the sown area in Ukrainian farms of all categories was only 43.1 thousand hectares, with the largest sown areas in Cherkasy (6.8 thousand hectares), Mykolaiv (6 thousand hectares), Kirovohrad (6 thousand hectares), Dnipro (5.6 thousand hectares) and Kherson (4.8 thousand hectares) regions (Fig. 6).

Sorghum occupies one of the first places among field crops in terms of grain yield stability, and it even exceeds fodder grasses in terms of green mass yield. Under irrigation, crops can form more than $10.0 \mathrm{t} / \mathrm{ha}$ of grain and $100.0 \mathrm{t} /$ ha of green mass ${ }^{10}$.

${ }^{9}$ Алдошин А., Самойленко А., Федоренко Е. та ін. Особливості насінництва соргових культур. Бюлетень Інституту сільського господарства степової зони НААН Украӥни. 2013. № 5. С. 107.

10 Федорчук М., Коковіхін С., Каленська С. та ін. Науково-теоретичні засади та практичні аспекти формування еколого-безпечних технологій вирощування та переробки сорго в степовій зоні України : монографія. Херсон : ФОП Бояркін Д. М., 2017. С. 118. 


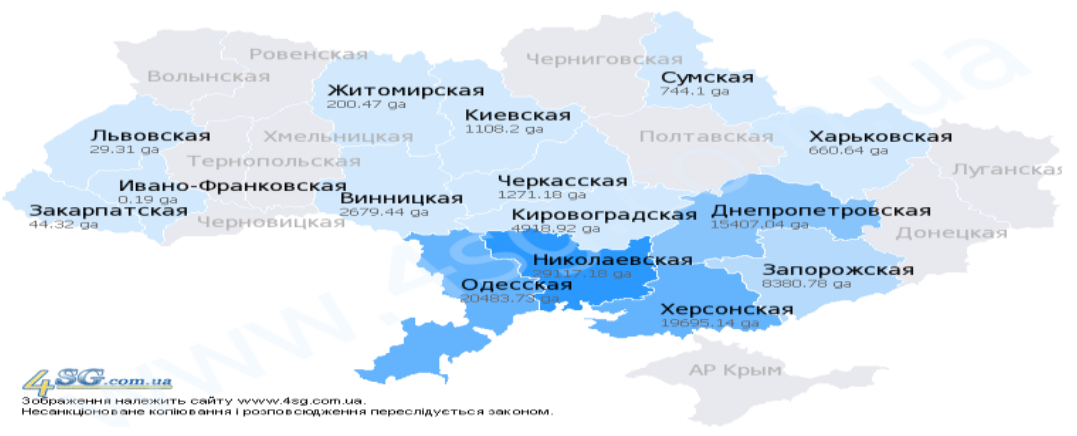

Fig. 5. Agricultural map of sorghum acreage in $2017 \mathrm{yr}$

Source: electronic resource http://sorgo-krasnoe.4sg.com.ua/agromap2017.php

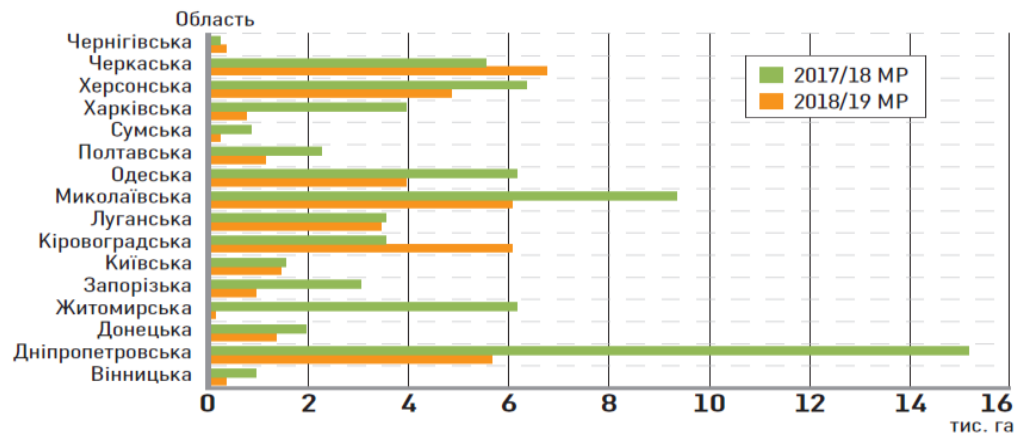

Fig. 6. Dynamics of sorghum acreage in Ukraine 2017/18 yrs and 2018/2019 yrs Marketing Year

Source: electronic resource https://www.zerno-ua.com/journals/2018/ dekabr-2018-god/u-borgu-pered-sorgo/

Despite the value of this crop, the production of grain sorghum in Ukraine is insignificant and unstable. However, due to the achievements of breeding, the development of intensive cultivation technologies and relatively favorable grain market conditions, sorghum crops are significantly increasing.

Over the past 20 years Ukraine has experienced quite serious climate changes. Therefore, agricultural producers have to reorient themselves to new crops. Increasingly, Ukrainian farmers are betting on such droughtresistant cereals as sorghum. 
The development of the sorghum market is hindered by the low awareness of producers about the main elements of the technology of growing this crop, as well as the fact that there is no processing and marketing of these products.

At the same time, the potential of sorghum crops in Ukraine is still far from being revealed. Growing this crop in Ukraine will increase the return on land in the southern regions of our country and stabilize grain production.

Investing money in sorghum production is promising due to the growing demand for this crop in the domestic and foreign markets. In Ukraine, the main areas in which the use of sorghum is promising are animal husbandry and the alcohol industry. The seeds of this plant have a high content of nutrients and it can be used to prepare high-quality feed mixes no worse than from corn grains. And due to its high starchiness, 38-39 Dal of alcohol is obtained from one ton of sorghum, which exceeds its amount produced from wheat (35-36 Dal), and is close to the yield of alcohol from corn (38-40 Dal).

Ukraine has the necessary and quite favorable conditions for the production of liquid biofuels, both in terms of land resources and plant potential, and in terms of the availability of its own production facilities (Fig. 7).

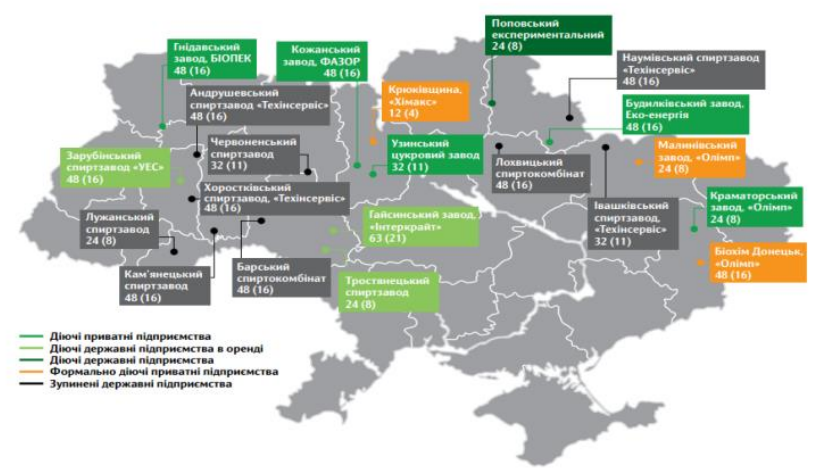

Fig. 7. Placement of processing enterprises for the production of ethyl alcohol

Source: electronic resource http://www.ukrsugar.com/uk/post/ biopalivo-majbutne-cukrovoi-galuzi-ukraini 
Already today, the potential of grown aboveground biomass in Ukraine, suitable for the cost-effective production of liquid biofuels (bioethanol and biodiesel), gives grounds to assert the prospects of this direction. The annual technically achievable energy potential of liquid biofuels in Ukraine has recently been equivalent to 1 million tons of oil equivalent.

Its use makes it possible to save about 1.2 billion $\mathrm{m} 3$ of natural gas annually. The greatest potential for the production of liquid biofuels is now concentrated in the Vinnitsa and Poltava regions, where it is more than 90 thousand tons oil equivalent per year.

Already in $2017 \mathrm{yr}$ the energy of biofuels and agricultural waste fully in the structure of total energy consumption in Ukraine over the past decade has increased from $1.1 \%$ up to $3.4 \%$, that is, three times (Fig. 8).

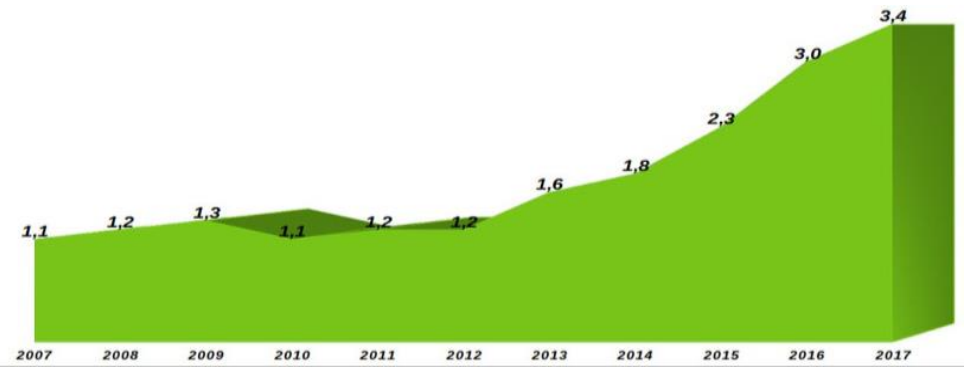

Fig. 8. Energy of biofuels and waste in the structure of total energy consumption in Ukraine

Source: electronic resource http://energy.esco.agency/rubriki-zhurnala/ biotoplivnaja-jenergetika/5196/perspektivi-viroshhuvannja-energetichnih-kultur

The Verkhovna Rada of Ukraine has registered Draft Law No. 7348, which provides for a mandatory norm for adding bioethanol and biodiesel to all types of fuel sold in the country. The draft law provides that from January 1, 2019 yr the total capacity of bio-components for gasoline should be $5 \%$ by weight, and from July 1, $2020 \mathrm{yr}$ it should be at least $7 \%$.

Fines are provided for refusing to add bio-components to automobile fuel. If the document is approved, a guaranteed sales market for 350 thousand tons of ethanol per year will be created in Ukraine. 


\section{Variety-hybrid potential of sorghum crops in Ukraine}

The most distinctive feature of the climate of the $20^{\text {th }}$ century at the beginning of the $21^{\text {st }}$ century was global warming, characterized by an increase in surface temperature of air and soil, nerve-measuring precipitation. The decrease in the yield of the main agricultural crops due to unfavorable climatic conditions can reach 50-60\%, and in some years even more. The duration of droughts may be one of the most serious concerns about the impact of climate change on agriculture at both the regional and global levels. As one of the optimal ways to solve this problem is the selection of crops that are characterized by high adaptability, yield and drought resistance. Such a crop is sorghum, which has significant advantages over other grains in terms of technology of cultivation, storage, threshing, use for the preparation of high-quality food products and nutritional value.

Thus, grain sorghum plants are more plastic than other crops, in particular corn, when grown in conditions of lack of moisture at high temperatures. The use of new highly productive sorghum hybrids is one of the most cost-effective and efficient ways to increase yields, their stability and improve grain quality.

Sorghum crops have a number of advantages over other grain crops, they are the least whimsical and most adapted to environmental conditions, which puts them in the first place for growing in the conditions of modern climate change.

The expediency of growing sorghum is due to its high productivity and versatility of use. This is an unpretentious crop that is able to provide high levels of yield in different climatic conditions on a variety of soils (light and heavy clay) due to a powerful, deeply penetrating root system.

The use of varietal plant resources is one of the most important links in agriculture - the basis of economic and social development of the state. The most effective and cost-effective is the widespread introduction of new varieties and hybrids with a genetically determined level of adaptation to the conditions of soil and climatic zones of their cultivation.

As of 2020 yr 187 varieties and hybrids of sorghum crops were registered in the State Register of plant varieties suitable for distribution in Ukraine (Table. 1). 


\section{Table 1}

Number of varieties and hybrids of sorghum crops, registered in the State Register of plant varieties and suitable for distribution in Ukraine as at 01.06.2020

\begin{tabular}{|c|c|}
\hline Culture & In total, PCs. \\
\hline Grain sorghum (parent components) & 13 \\
\hline Grain sorghum & 95 \\
\hline Soriz & 19 \\
\hline Broom sorghum parent component & 1 \\
\hline Broom sorghum & 7 \\
\hline Sugar sorghum parent component & 7 \\
\hline Sugar sorghum & 27 \\
\hline Sorghum-Sudanese hybrids & 16 \\
\hline Perennial sorghum & 2 \\
\hline
\end{tabular}

Note: Compiled according to the site's data ( IAC Аграрії разом

At the moment, extensive complex research with sorghum crops in Ukraine is being carried out in the Dnipropetrovsk region by the Institute of Agriculture of Steppe regions of the National Academy of Sciences of Ukraine, Sinelnikovskaya Experimental Station, in the Kherson region Genicheskaya Experimental Station, Institute of irrigated agriculture of the National Academy of Sciences of Ukraine, in the Odessa region - Breeding and Genetic Institute-National Center for seed and variety studies and Odessa State Agrarian University and other institutions. The high yielding varieties and hybrids created by them over the long term period of experimental work puts the sorghum crop at a new stage of introduction into production.

\section{Using sorghum as an energy crop}

The demand for energy has increased over the years due to factors such as population growth, the expansion of large cities, and rising living standards. This has led to an increase in global pollution, a reduction in natural resources and productive areas, and a certain disappearance of plant and animal species.

The negative effects associated with increased energy production can be mitigated by using renewable energy sources and achieving increased efficiency of the corresponding production processes, so that energy consumption is reduced without affecting the quality of life ${ }^{11,12}$.

${ }^{11} \mathrm{Su}$, Y., Zhang, P. An overview of biofuels policies and industrialization in the major biofuel producing countries. Renew. Sust. Energ. Rev. 2015. № 50. P. 999.

12 Rocha, A.; Araújo, A.; Carvalho, A.; Sepulveda, J. A. New Approach for Real Time Train Energy Efficiency Optimization. Energies. 2018. № 11. DOI:10.3390/en11102660. 
Energy balances allow us to evaluate and compare the efficiency of methods for the production of alternative energy resources ${ }^{13}$. Energy efficiency contributes to the sustainable development of agriculture ${ }^{14}$ and it takes into account the energy invested and produced in the production process. However, energy consumption and production vary greatly between crops and production systems. Thus, the efficiency of the production process is measured by the ratio between the benefits received and the resources used. Therefore, it is important to choose a reasonable analysis method and the right tools. An efficient process requires that the energy invested in biofuel production, including its agricultural and industrial stages, is less than the energy that leaves the system $^{15}$.

Biofuels are usually derived from plant or animal biomass and provide a viable source of energy. A number of studies have determined that energy plants can reduce greenhouse gas emissions ${ }^{16}$. According to foreign researchers ${ }^{17}$, the most common biomass for fuel production includes corn, wheat, sugar cane, sugar beet and sugar sorghum. These sources show great potential for both replacing conventional fuels and reducing polluting emissions. In addition, sugar sorghum shows great adaptability to drought, high soil air temperatures and soil salinity. Its characteristics make the crop an ideal raw material for sustainable biofuel production.

However, its yield varies significantly depending on the variety, growing conditions (soil, water, climate, pests and diseases), varieties and hybrids, and elements of agricultural technology ${ }^{18}$. Compared to other agricultural crops, sugar sorghum uses significantly less moisture

${ }^{13}$ Haciseferogullari, H., Acaroglu, M., Gezer, I. Determination of the energy balance of the sugar beet plant. Energ. Source. 2003. № 25. P. 20.

14 Pervanchon, F., Bockstaller, C., Girardin, P. Assessment of energy use in arable farming systems by means of an agro-ecological indicator: the energy indicator. Agric. Syst. 2002. № 72. P. 165.

${ }^{15}$ Larnaudie, V., Rochon, E., Ferrari, M. D., Lareo, C. Energy evaluation of fuel bioethanol production from sweet sorghum using very high gravity (VHG) conditions. Renew. Energ. 2016. № 88. P. 284.

${ }^{16}$ Mathur, S., Umakanth, A. V., Tonapi, V. A., Sharma, R., Sharma, M. K. Sweet sorghum as biofuel feedstock: recent advances and available resources. Biotechnol. Biofuels. 2017. № 10. P. 146.

${ }^{17}$ Bai, Y., Luo, L., van der Voet, E. Life cycle assessment of switchgrass-derived ethanol as transport fuel. The Int. J. Life Cycle Assess. 2010. № 15. P. 470.

${ }^{18}$ Mishra, J. S., Kumar, R., Rao, S. S. Performance of sweet sorghum (Sorghum bicolor) cultivars as a source of green fodder under varying levels of nitrogen in semi-arid tropical India. Sugar Tech. 2017. № 19. P. 533. 
and fertilizers due to the favorable combination of its agrotechnical and technological characteristics, which makes it one of the best raw materials in the production of biofuels ${ }^{19,20,21}$.

Corn silage is most widely used for agricultural biogas plants. The main advantage of corn silage over other substrates is that it guarantees stable production of biogas and methane, which greatly facilitates the dosage of the substrate into the fermentation chamber and stabilizes the operation of the cogeneration plant. Sorghum is an alternative crop for the production of biofuels and biogas. Sorghum plants are more resistant to drought than corn, and their biomass yields are higher, especially in years with low rainfall. Sorghum is more tolerant of various environmental conditions, and its production is less energy-intensive compared to corn. This is an extremely important factor, since energy crops should have a positive impact on the energy balance. Energy crops should be characterized not only by high biomass yields, but also by low energy costs associated with agricultural operations. Only agricultural crops with a high energy potential and a high energy efficiency coefficient guarantee a constant and reliable supply of raw materials for converting them into energy.

Sugar sorghum, as an energy and fodder crop, is of great practical interest for agriculture in general and especially for the arid regions of Ukraine. Sorghum is able to provide high yields in heat and drought conditions. The positive properties of this crop include the fact that it is undemanding to the quality of soils. This is an extremely valuable crop for regions where other plants are low-yielding due to insufficient precipitation, which is typical for the conditions of southern Ukraine. Sorghum often surpasses corn in yield.

The introduction of intensive sorghum cultivation technology is important not only in the agronomic aspect, but also from the point of view of economy. The economic efficiency of growing sugar sorghum is significantly increased by growing it against the background of optimal fertilizer rates.

${ }^{19}$ Cosedido, V., Vacas, R., Macarulla, B., Gracia, M. P., Igartua, E. Agronomic and digital phenotyping evaluation of sweet sorghum public varieties and F1 hybrids with potential for ethanol production in Spain. Maydica 2013. № 58. P. 42-53.

${ }^{20}$ Barcelos, C. A., Maeda, R. N., Santa Anna, L. M., Pereira, N. Sweet sorghum as a whole-crop feedstock for ethanol production. Biomass bioenergy. 2016. № 94. P. 50.

${ }^{21}$ Bonin, C. L., Heaton, E. A., Cogdill, T. J., Moore, K. J. Management of sweet sorghum for biomass production. Sugar tech. 2016. № 18. P. 155. 


\section{Characteristics of soil fertility and features of climatic conditions of the Steppe zone of Ukraine}

Until recently, steppes occupied about $40 \%$ of the territory of present-day Ukraine. Despite the vast expanses and uneven terrain, steppe vegetation for many centuries formed a dense sod, which protected the soil from erosion. Steppes have also shaped and maintained sustainable biological diversity by transforming organic remains and regulating populations of organisms.

The Steppe suffered the greatest losses during the XIX-XX centuries as a result of burning dry vegetation, excessive grazing and anthropogenic transformation of primary steppe ecosystems: plowing, afforestation, construction (roads, dams, canals), irrigation and industrial development (installation of wind turbines, solar power plants, etc.).

Steppe as a geographical zone and steppe as an ecosystem in the XXI century are no longer synonymous, as it as an integral ecosystem is almost destroyed today. Only small islands of fragments of the steppe zone (within 1-4 \%) have so far remained on slopes, terraces, in gullies, on saline and stony soils, separate protected areas and military training grounds. These territories of Ukraine store invaluable genetic resources, which are a habitat for the development of knowledge-intensive industries and almost $30 \%$ of all species of flora and fauna listed in the Red Book of Ukraine.

The modern steppe is a combination of agricultural landscapes with man-made and residential landscapes. According to the conclusions of environmental science, the viability of the biosphere is possible only under conditions when natural ecosystems will occupy $67-80 \%$ of the land area, and their bio-productivity will be equal to the average global indicators. Plowing steppes and uprooting forests, a person changes not only vegetation, but also other conditions that determine the water, air and thermal regimes of the soil. Changes in these conditions lead to changes in microbiological activity in the soil, increased biochemical processes of nutrient mobilization, which, in turn, changes the nutrient regime and soil fertility, and also leaves a significant imprint on the formation of various types of soils and their properties.

Steppe is an economic category in understanding the potential fertility of the main types of soils that are the property of our state, the reasonable use of which can ensure the economic growth of Ukraine. Due to the high plowing of the territory, soil scientists mainly study agrozems chornozems under agricultural crops in order to monitor their properties 
and improve agronomic qualities and fertility, deal with the problems of soil degradation and dehumification.

The steppe zone of Ukraine is one of the most developed agricultural landscape territories of the state, covering partially or completely Kharkiv, Luhansk, Donetsk, Dnipropetrovsk, Zaporozhye, Kirovohrad, Kherson, Mykolaiv, Odessa regions, as well as the flat part of the Crimean Peninsula. It occupies almost 25 million hectares, including agricultural land as 16.4 million hectares, of which arable land as 13.3 million hectares, or $82 \%$.

According to the soil and climatic conditions in the steppe zone, there are two subzones such as the Northern and Southern steppes.

The soil cover of the steppe zone is quite diverse. In its northern part, the most common soils are ordinary chernozems. They occupy $81.1 \%$ of the total area of the zone. The following subtypes are found among common chernozems: low-humus $(50.3 \%)$ and medium-humus $(30.8 \%)$. In addition to them, there are also chernozems on Sands, chernozems on dense carbonate-free rocks, and residual saline chernozems. In the lower parts of the relief, sod-gley, meadowchernozem, meadow, meadow-marsh, moist soils, as well as solonets are common. In the central part of the northern steppe, the subtype of ordinary medium-thick chernozems prevails with a humus profile depth of up to 70-80 cm and a humus content of 5-6\%. To the south of these types of soils are low-power ordinary chernozems with a humus layer of $40 \mathrm{~cm}$ and a humus content of 4-5\%. They are less favorable for crop production, differ in the dispersion of the arable layer, the presence of a compacted transition horizon and local layers of water-soluble salts.

The southern Steppe subzone is divided into two independent subzone such as the Southern and dry Steppe subzone. The region of southern Ukraine includes the territory of four regions (Zaporizhzhia, Mykolaiv, Odesa, Kherson) and Crimea. In the steppe agrolandscapes of Ukraine, southern chornozems and chestnut soils are most common. Since in the steppe zone on land areas, the soil is not completely wetted (auto-field mode), carbonates accumulate in them, and in the Southern Steppegypsum and easily soluble sulfates and chlorides. This process is enhanced by plants with powerful and deep-penetrating root systems (corn, sunflower, Sudanese grass, etc.) and earthmoving animals. As a result of the delayed mineralization of plant residues due to dryness and a relatively short heat period, significant reserves of humus accumulate in the soil, which is delayed due to the high content of calcium in the soil. 
The soil profile consists of two layers - humus-accumulative and illuvial carbonate. Loess and loess-like loams are widespread, in the formation of which the processes of weathering and biological cycle in arid conditions played an important role. They are a relict oruvial layer of former fertile soils.

The soils of the steppe zone of Ukraine vary from ordinary chornozems in the north to dark chestnut and chestnut in the South. In the same direction, the level and mineralization of ground water increases, salinity of soils increase. On large areas of agricultural landscapes of the steppe region of Ukraine, intensive flushing and linear erosion of soils occur, which is due to the lack of forests, rapid snowmelt, heavy precipitation, violations in the tillage system, etc., which affects their potential fertility (Fig. 9).

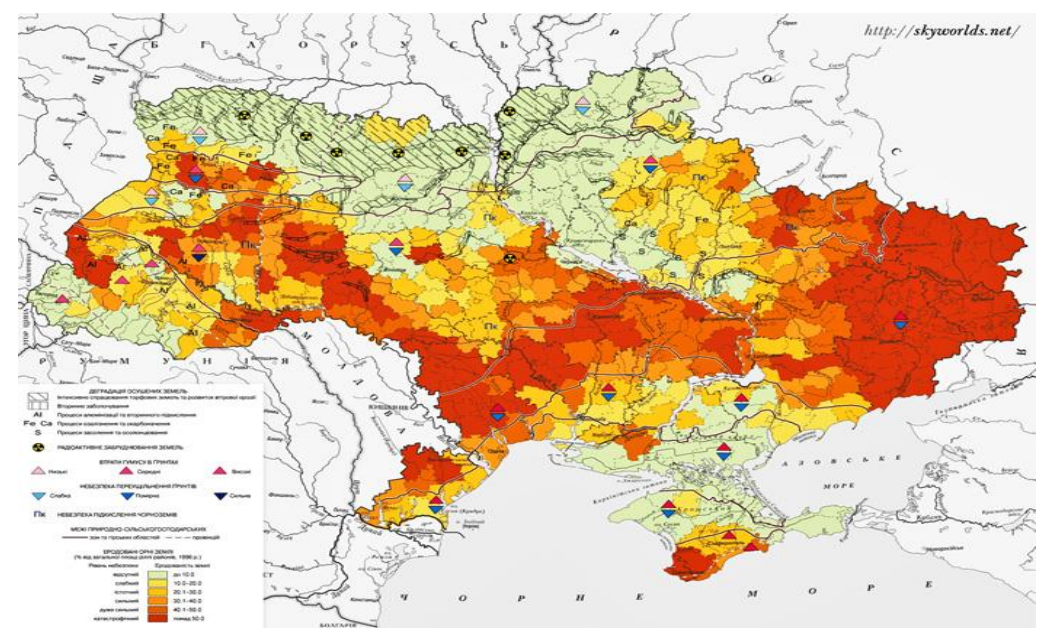

Fig. 9. Soil condition of Ukraine:

the darkest color indicates the regions where it is catastrophic

Source: infographic from the site skyworlds.net

In addition to zonal soils with well-defined boundaries, there are also azonal soils that occur in different places of the southern Steppe subzone. These soils include meadow-chornozem, sod-sand, and weakly fortified sands. These soils cover significant areas in floodplains of rivers and on river terraces. According to their geomorphological and hydrogeological conditions, land reclamation characteristics, and agronomic properties, 
most soils in the south of Ukraine are suitable for irrigation. However, each type and type of soil cancellation requires its own approaches that take into account its physical and chemical properties, fertility, etc.

A significant part of the soil cover of the Southern steppe is represented by Southern chornozem with a reduced humus content as 3.3 up to $3.5 \%$ or less in the arable layer. Such soils are characterized by a loose composition, good structuring and high biological activity, salts in them are accumulated at great depths. Chestnut soils are also common in the steppe agrolandscapes of the Primorsky lowland. The subtype of dark chestnut soils is similar to Southern chernozems, but is characterized by a lower humus content (less than $3 \%$ ), close salt content $(2.0-2.5 \mathrm{~m})$, dispersion and reduced water permeability from the surface, high density of the transition horizon and the presence of sodium in the lower layers. Complexes of medium - and highly saline chestnut soils with solonets are common in Prisivashsha. Solonets and saline soils are characterized by low moisture capacity, floating when moistened and low absorption capacity. Unsatisfactory physical properties are characteristic of the vast majority of meadow-chornozem, sod-gley and saline gley soils of pods (closed depressions), which occupy significant areas of the Southern Steppe.

In terms of mechanical composition, medium - and heavy-loamy soils predominate in the south of Ukraine, while light-loamy soils occupy smaller areas. Sandy loam is mainly concentrated in the forest-steppe, and in the south light soils predominate in the zone of the Krasnoznamenskaya irrigation system.

Steppe soils of Ukraine have a high potential fertility. So, according to Karmanov I. I., according to the ratio of the probable fertility of a certain soil to the optimal provision of fertility resources of the reference soil (chornozem of the slightly alkaline heavy-duty Krasnodar Territory), it is $0.96-1.00$ for chornozems, and for dark chestnut soils it decreases down to 0.86 . However, in production practice, even with high agricultural technology, this ratio is often 0.56 up to 0.63 and 0.53 up to 0.56 , respectively, decreasing within these limits from West to Southeast.

The main factor of insufficient productivity of these agricultural landscapes is the lack of moisture, which determines the primary importance of using irrigation to obtain the planned level of yield of field crops. The most significant from the point of view of irrigation applications are the properties of soils in the steppe region of the zone. Thus, chornozems of all subtypes and dark chestnut soils prevailing on irrigated lands have a high overall porosity (within $50 \%$ of the soil composition density), which indicates a high moisture and air capacity 
and degree of permeability. It is noticeably lower due to the peculiarities of genesis only on sod-podzolic soils (38-42\%) and on solonets (40-46\%). Aeration values are high as 33.1 up to $43.3 \%$ on all types of soils, except for medium-salt and solonets, where it decreases slightly (27.4 up to $31.0 \%$ ). Most soils in the south of Ukraine are characterized by a high active moisture capacity $-80-100 \mathrm{~mm}$, decreasing to $70 \mathrm{~mm}$ on sparsely distributed soils. Such indicators are a positive property of the zone's soils, which makes it possible to implement the strategy under various irrigation modes (biologically optimal, resource-saving, soil-protective, synchronized, etc.). With a high evaporation rate, it creates prerequisites for efficient use of available water and technological resources using various methods of artificial humidification, allowing you to transfer the timing of irrigation within certain limits, without going beyond the range of optimal humidification or differentiated supply of irrigation water.

Features of the climate on the territory of Ukraine are caused by the interaction of the main climate forming factors such as the intensity of solar radiation and atmospheric circulation. The southern subzone of the steppe of Ukraine is characterized by a significant shortage of natural moisture, periodic droughts and dry phenomena that negatively affect the efficiency of agricultural production. Spring droughts at the beginning of the growing season of agricultural crops are local in nature with a probability of up to 50$60 \%$. Most often, they appear in the narrow Black Sea zone in the south of the Kherson region, adjacent to Sivash. In this territory, on average for ten years, they can be repeated 5-6 times. Summer droughts are more common than spring and autumn droughts, and they recur almost annually. Their greatest probability (80-90\%) is observed in the southern coastal regions of the Kherson region and in the southern part of the Crimea, which coincides with the growing season of late crops. The temperate continental climate of southern Ukraine, with insufficient and unstable moisture, as well as significant resources of solar radiation, has formed steppe subboreal (semiarid) agricultural landscapes.

According to the climatic conditions in the Steppe there are three subzones:

- southern (Kherson, Mykolaiv, part of Odessa regions, steppe regions of Crimea);

- central (Dnipropetrovsk, Zaporizhia, southern parts of Kirovohrad and Donetsk regions);

- northern (northern part of Kirovohrad and Donetsk regions, Luhansk region).

To characterize the solar regime of a certain area, you need to use such a characteristic as the duration of sunlight (table. 2). 
Table 2

Monthly duration of sunlight during the growing season of plants, h (according to K. T. Logvinov)

\begin{tabular}{|c|c|c|c|c|c|c|c|c|}
\hline \multirow{2}{*}{ Region } & \multicolumn{7}{|c|}{ Months } \\
\cline { 2 - 10 } & $\mathbf{1 V}$ & $\mathbf{V}$ & V1 & V11 & V111 & $\mathbf{1 X}$ & $\mathbf{X}$ & X1 \\
\hline Luhansk & 176 & 252 & 279 & 316 & 284 & 228 & 152 & 48 \\
\hline Dnipropetrovsk & 178 & 245 & 278 & 308 & 280 & 212 & 140 & 63 \\
\hline Donetsk & 185 & 262 & 294 & 324 & 293 & 228 & 143 & 66 \\
\hline Zaporizhzhia & 178 & 245 & 286 & 317 & 302 & 234 & 155 & 63 \\
\hline Kirovohrad & 178 & 250 & 277 & 313 & 280 & 226 & 149 & 46 \\
\hline Mykolaiv & 203 & 272 & 289 & 336 & 317 & 248 & 166 & 69 \\
\hline Odesa & 208 & 277 & 305 & 349 & 322 & 250 & 175 & 69 \\
\hline Kherson & 199 & 279 & 311 & 350 & 325 & 246 & 171 & 76 \\
\hline Crimea & 214 & 282 & 315 & 357 & 334 & 255 & 190 & 117 \\
\hline
\end{tabular}

The longest duration of solar lighting in Ukraine on average per year is 2150-2450 hours. The sunniest period is May-August, when the duration of sunlight in Polesie is $48-60 \%$ of the possible time and increases up to 70-75\% in the south and in the Crimea.

The need for heat varies from crop to crop. For each phase of plant growth and development, there are minimum, optimal, and maximum temperatures. The beginning of the growing season in the southern Steppe occurs in late March, and in the northern steppe it occurs in early April. In agricultural production, it is important to take into account the transition of air temperature through $0,5,10,15^{\circ} \mathrm{C}$ (table 3 )

Table 3

Duration of the air temperature transition period after $0,5,10,15^{\circ} \mathrm{C}$, days

\begin{tabular}{|c|c|c|c|c|}
\hline \multirow{2}{*}{ Region } & \multicolumn{4}{|c|}{ Air temperature } \\
\cline { 2 - 5 } & $\mathbf{0}^{\circ} \mathbf{C}$ & $\mathbf{5}^{\circ} \mathbf{C}$ & $\mathbf{1 0}^{\circ} \mathbf{C}$ & $\mathbf{1 5}^{\circ} \mathbf{C}$ \\
\hline Luhansk & 243 & 202 & 167 & 125 \\
\hline Dnipropetrovsk & 252 & 211 & 170 & 130 \\
\hline Donetsk & 249 & 205 & 166 & 127 \\
\hline Zaporizhzhia & 263 & 215 & 176 & 133 \\
\hline Kirovohrad & 253 & 209 & 168 & 121 \\
\hline Mykolaiv & 271 & 222 & 178 & 133 \\
\hline Odesa & 282 & 226 & 181 & 134 \\
\hline Kherson & 246 & 224 & 181 & 136 \\
\hline Crimea & 308 & 247 & 187 & 132 \\
\hline
\end{tabular}


The beginning of the period with an average daily temperature above $15^{\circ} \mathrm{C}$, which coincides with the beginning of the most intense vegetation, in the steppe zone falls on the second decade of May, and the end of this period in the northern steppe falls on the second decade, and in the Southern it falls on the third decade of September.

The average long-term sums of active temperatures in the northern steppe range from 2900 up to $3100^{\circ} \mathrm{C}$, and in the southern steppe they range from 3200 up to $3500^{\circ} \mathrm{C}$. The sums of these temperatures with a probability of up to $90 \%$ are slightly smaller; in the northern steppe they are 2550 up to $3000^{\circ} \mathrm{C}$, in the southern steppe they are 3000 up to $3200^{\circ} \mathrm{C}$.

Weather prospects in the coming decades include increased heat, lack of moisture and migration of agroclimatic zones. Thus, according to the Ukrainian Hydrometeorological Center, over the past 30 years, the agroclimatic zones steppe, forest-steppe and Polesie with changes in the average annual temperature and the amount of accumulated heat have already shifted $200 \mathrm{~km}$ to the North during 2012-2015 yrs (fig. 10).

The consequences of global climate change are becoming more and more noticeable in the northern Black Sea region, especially due to significant deviations from the basic laws of agriculture, including excessive growth in the structure of crop rotations of technical group crops, in particular sunflower crops. This encourages specialists and scientists to diversify the structure of acreage, taking into account the adaptive potential of agricultural crops. One of these among all cereals, in our opinion, are sorghum crops, since by their characteristics they are the least whimsical and most adapted to environmental conditions when grown in arid regions of the country.

According to the United Nations World Meteorological Organization $(\mathrm{WMO})^{22}$, the average global temperature for the period 2015-2019 was higher than the climatic norm by 1.1 degrees Celsius compared to the pre-industrial era (1850-1900), and by 0.2 degrees Celsius than in 20112015. There is a high probability that abnormal weather events (fires, hot days, precipitation, etc.) in many regions will become more intense, soil and air droughts ${ }^{23}$ will occur more often and they last longer, which will lead to a significant decrease in the productivity of most plants by the type of carbon dioxide fixation C3 (wheat, rye, rice, oats, sugar beet and others) ${ }^{24}$.

22 Середня глобальна температура може піднятися на $1,5^{\circ} \mathrm{C}$ у найближчі п’ять років - дослідження. URL: https://inspired.com.ua/stream/serednya-globalnatemperatura-mozhe-pidnyatysya-na-1-5-c-u-najblyzhchi-p-yat-rokiv-doslidzhennya.

23 Зміна клімату. URL : https://www.amnesty.org.ua/zmina-klimatu.

24 C3, C4 і CAM рослини: Адаптація до зміни клімату. URL: https://www.greelane.com/uk/\%Dcam-plants-processes-172693. 


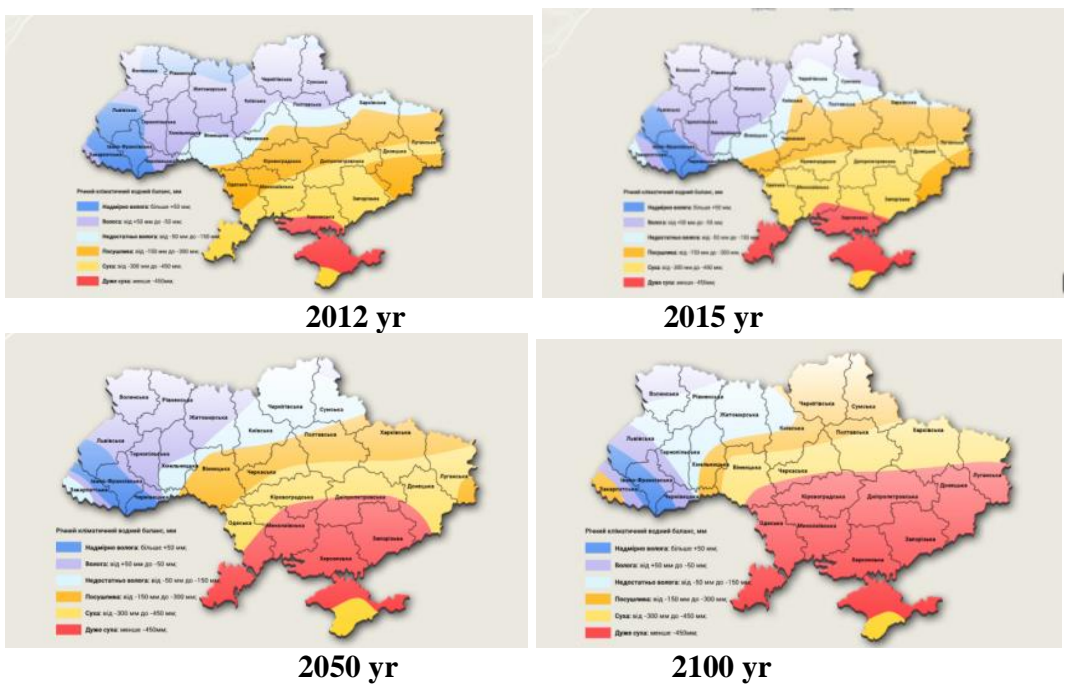

Fig. 10. Zoning of the territory of Ukraine according to the annual climatic water balance

Source: https://landlord.ua/wp-content/page/anomalnyi-rik/

At the same time, plants of the C4 type (amaranth, corn, sorghum, millet), due to their special morphological and physiological and biochemical characteristics, are more resistant to adverse environmental factors precisely because they are able to use water more economically and form a stable productivity ${ }^{25,26,27}$.

So, despite the intensification of agriculture, obtaining high and stable yields of agricultural crops in the steppe zone of Ukraine, in the presence of other sufficiently favorable factors (soil fertility, sufficient heat and light), is limited by a lack of moisture and nutrients and, first of all, nitrogen ${ }^{28}$. Under such conditions, there is a decrease in plant

${ }^{25}$ Gowik U., Westholl P. 2011. The path from C3 to C4 photosynthesis. Plant Physiol. № 155. P. 56-63.

${ }^{26}$ Lundgren M. R., Osborne C. P., Christin P.-A. 2014. Deconstructing Kranz anatomy to understand C4 evolution. J. Exp. Bot. № 65. P. 3362.

27 Позитивний вплив вмісту вуглекислого газу на розвиток рослин. URL: http://agro-yug.com.ua/archives/9325.

${ }^{28}$ Гамаюнова В., Коваленко О.., Хоненко Л. Сучасні підходи до ведення землеробської галузі на засадах біологізації та ресурсозбереження : колективна монографія / за ред. П. В. Писаренка, Т. О. Чайки, І. О. Яснолоб. Полтава ПДАА, 2018. 324 с. С. 239. 
productivity and crop quality indicators, which makes it necessary to use fertilizers in their interaction with irrigation.

\section{CONCLUSIONS}

Based on the results of a review of literature sources and research initiated in $2020 \mathrm{yr}$ on the development of technological elements for growing sorghum crops in the arid Southern steppe zone of Ukraine it is possible to draw the following conclusions:

The most distinctive feature of the climate characteristic of the late twentieth and early twenty-first centuries was global warming, characterized by an increase in surface air temperature. The duration of droughts, rainless days that can last 100 days or more, is clearly one of the most serious problems of the impact of climate change on agriculture, both at the regional and global levels. One of the most optimal solutions to this problem is the selection of crops that are characterized by high yields and drought resistance. Such a crop is sorghum, which has many advantages over other grains in terms of cultivation, storage, threshing, use for the production of feed, food products and biofuels.

Sorghum crops are more effective among grain crops, they are less whimsical and most adapted to environmental conditions, which puts them in the first place for growing in conditions of changing the main components of the climate.

The production of sugar sorghum silage is a promising area due to its high energy efficiency, the value of which in the conditions of southern Ukraine can exceed 11. The maximum values of this indicator in some countries of the world reach 18 .

Grain sorghum has a lower value of the energy efficiency coefficient compared to sugar sorghum silage. Correlation and regression analysis determined that this is most affected by the sowing period. Studies conducted in the National Research Center of Mykolaiv NAU have established that the early sowing period provides a significant increase in the energy efficiency of silage sorghum cultivation.

\section{SUMMARY}

In recent years, in Ukraine, attention to sorghum culture has increased significantly, which is primarily associated with climate warming. As the environment deteriorates, the search for new clean renewable energy sources becomes more urgent. Today in Ukraine one of the most promising bioenergy crops is sorghum.

In the world, sorghum is also increasingly seen as promising for growing not only a grain, but also a bioenergy crop that can make the most of the existing agro-resource potential of arid territories. An important advantage of 
sorghum compared to other crops is its ability to easily tolerate high temperatures, effectively use precipitation from the second half of summer, continue to grow after a long drought and form a fairly high yield, which allows it to grow in the arid regions of southern Ukraine.

\section{References}

1. Продан I. У боргу перед сорго. URL: https://www.zerno-ua.com/ journals/2018/dekabr-2018-god/u-borgu-pered-sorgo.

2. Біопаливо - майбутне цукрової галузі України. URL: http://www.ukrsugar.com/uk/post/biopalivo-majbutne-cukrovoi-galuziukraini.

3. Перспективний ринок сорго. URL: http:/agrobusiness.com.ua/agro/ekonomichnyi-hektar/item/7957-perspektyvnyisvitovyi-rynok-sorho.html.

4. Супіханов Б. Нішеві культури. Вісник аграрної науки. 2017. № 4. C. $58-64$.

5. Попова Г. Врятуватися від спеки. Агро\$гроші. 2013. № 1. С. $16-19$.

6. Федорчук М., Коковіхін С., Каленська С. та ін. Агротехнологічні аспекти вирощування енергетичних культур в умовах півдня України : навч. посібник. Херсон : ФОП Бояркін Д. М., 2017. 160 с.

7. Бойко М. Агробіологічне обгрунтування елементів технології вирощування гібридів сорго зернового в Південному Степу України : дис. ... канд. с.-г. наук : 06.01.09 «Рослинництво». Державний вищий навчальний заклад «Херсонський державний аграрний університет». Херсон, 2017. 230 с.

8. Звіт лабораторії селекції сорго Інституту зернового господарства НААН України за 2006-2011 pp. 23 с.

9. Алдошин А., Самойленко А., Федоренко Е. та ін. Особливості насінництва соргових культур України. Бюлетень Інституту сільського господарства степової зони НААН. 2013. № 5. С. 104-110.

10. Федорчук М., Коковіхін С., Каленська С. та ін. Науковотеоретичні засади та практичні аспекти формування екологобезпечних технологій вирощування та переробки сорго в степовій зоні України : монографія. Херсон : ФОП Бояркін Д. М., 2017. 160 с.

11.Su, Y., Zhang, P. An overview of biofuels policies and industrialization in the major biofuel producing countries. Renew. Sust. Energ. Rev. 2015. № 50. P. 991-1003. 
12.Rocha, A., Araújo, A., Carvalho, A., Sepulveda, J. A. New Approach for Real Time Train Energy Efficiency Optimization. Energies. 2018. № 11. DOI: 10.3390/en11102660.

13. Haciseferogullari, H., Acaroglu, M., Gezer, I. Determination of the energy balance of the sugar beet plant. Energ. Source 2003. № 25. P. 15-22.

14.Pervanchon, F.; Bockstaller, C.; Girardin, P. Assessment of energy use in arable farming systems by means of an agro-ecological indicator: the energy indicator. Agric. Syst. 2002. № 72. P. 149-172.

15.Larnaudie, V., Rochon, E., Ferrari, M. D., Lareo, C. Energy evaluation of fuel bioethanol production from sweet sorghum using very high gravity (VHG) conditions. Renew. Energ. 2016. № 88. P. 280-287.

16. Mathur, S., Umakanth, A. V., Tonapi, V. A., Sharma, R., Sharma, M. K. Sweet sorghum as biofuel feedstock: recent advances and available resources. Biotechnol. Biofuels. 2017. № 10. P. 146.

17.Bai, Y., Luo, L., van der Voet, E. Life cycle assessment of switchgrass-derived ethanol as transport fuel. The Int. J. Life Cycle Assess. 2010. № 15. P. 468-477.

18. Mishra, J. S., Kumar, R., Rao, S. S. Performance of sweet sorghum (Sorghum bicolor) cultivars as a source of green fodder under varying levels of nitrogen in semi-arid tropical India. Sugar Tech. 2017. № 19. P. 532-538.

19.Cosedido, V., Vacas, R., Macarulla, B., Gracia, M. P., Igartua, E. Agronomic and digital phenotyping evaluation of sweet sorghum public varieties and $\mathrm{F} 1$ hybrids with potential for ethanol production in Spain. Maydica. 2013. № 58. P. 42-53.

20.Barcelos, C. A., Maeda, R. N., Santa Anna, L. M., Pereira, N. Sweet sorghum as a whole-crop feedstock for ethanol production. Biomass bioenergy 2016. № 94. P. 46-56.

21.Bonin, C. L., Heaton, E. A., Cogdill, T. J., Moore, K. J. Management of sweet sorghum for biomass production. Sugar tech. 2016. № 18. Р. 150-159.

22.Середня глобальна температура може піднятися на $1,5^{\circ} \mathrm{C}$ у найближчі п'ять років - дослідження. URL: https://inspired.com.ua/ stream/serednya-globalna-temperatura-mozhe-pidnyatysya-na-1-5-c-unajblyzhchi-p-yat-rokiv-doslidzhennya.

23.3міна клімату. URL: https://www.amnesty.org.ua/zmina-klimatu.

24.C3, C4 і CAM рослини: Адаптація до зміни клімату. URL: https://www.greelane.com/uk/\%D0\%BD\%D0\%B0\%D1\%83\%D0\%BAp rocesses-172693. 
25. Gowik U., Westholl P. The path from C3 to C4 photosynthesis. Plant Physiol. 2011. № 155. P. 56-63.

26.Lundgren M. R., Osborne C. P., Christin P.-A. Deconstructing Kranz anatomy to understand C4 evolution. J. Exp. Bot. 2014. № 65. P. 3357-3369.

27.Позитивний вплив вмісту вуглекислого газу на розвиток рослин. URL: http://agro-yug.com.ua/archives/9325.

28. Гамаюнова В., Коваленко О., Хоненко Л. Сучасні підходи до ведення землеробської галузі на засадах біологізації та ресурсозбереження : колективна монографія / за ред. П. Писаренка, Т. Чайки, I. Яснолоб. Полтава : ПДАА, 2018. 324 с. С. 232-241.

Information about the authors: Gamayunova Valentyna Vasylivna, Doctor of Agricultural Sciences, Professor, Head of the Department of Agriculture, Geodesy and Land Mykolayiv National Agrarian University 9, Georgiya Gongadze str., Mykolayiv, 54020, Ukraine

Khonenko Liubov Gryhorivna, $\mathrm{PhD}$ of Agricultural Sciences, Associate Professor at the Department of Crop and Horticulture Mykolayiv National Agrarian University 9, Georgiya Gongadze str., Mykolayiv, 54020, Ukraine

Kovalenko Oleh Anatoliiovych, PhD of Agricultural Sciences, Head of the Department of Crop and Horticulture Mykolayiv National Agrarian University 9, Georgiya Gongadze str., Mykolayiv, 54020, Ukraine 